\title{
Doctrinal Issues in Evidence and Proof
}

\author{
Paul F. Rothstein \\ Georgetown University Law Center, rothstei@law.georgetown.edu
}

This paper can be downloaded free of charge from:

https://scholarship.law.georgetown.edu/facpub/2228

https://ssrn.com/abstract=3528628

Published as Evidence and Proof, Doctrinal Issues In, Entry, in 1 Encyclopedia of Law and Society: American and Global Perspectives (David Scott Clark ed., London: Sage 2007), pp. 519-524.

This open-access article is brought to you by the Georgetown Law Library. Posted with permission of the author. Follow this and additional works at: https://scholarship.law.georgetown.edu/facpub

Part of the Evidence Commons 


\title{
Doctrinal Issues in Evidence and Proof
}

\author{
Paul F. Rothstein \\ (Professor, Georgetown Law)
}

The word evidence ordinarily means the statements, events, items, or sensory perceptions that suggest the existence or nonexistence of, or truth or falsity of, another fact. Thus, one may say, "hoofbeats are evidence a horse may be passing." Proof is similar in meaning but may connote more certainty.

Evidence can also mean the study of either (1) how people make such inferences (especially when conjoined with the word proof) or (2) how law regulates information admissibility in the judicial context. Evidence in the latter sense is the name of a standard law school course in common law countries and a subject that is on all American state examinations for admission to the bar. As a subject in law, then, evidence traditionally encompasses only the legal rules and regulations governing the admissibility of evidence, inference, and argument, on questions of fact, in civil and criminal judicial trials. Surprising for American lawyers, most civil law countries do not have a separate basic course on evidence but, rather, fold it into the introductory course on procedure.

\section{Current Controversies about the Discipline of Evidence}

\section{The "New Evidence Scholarship"}

Some law professors in English-speaking countries and continental Europe subscribe to the so-called "new evidence" scholarship, which argues that legal studies should include the processes by which humans do or ought to reason about and reach conclusions concerning the weight and meaning of evidence. Law should tap the rich vein of information in disciplines such as logic, philosophy, and psychology that have been studying the matter for years.

This new scholarship partly returns to the beliefs of the renowned American evidence scholar John Henry Wigmore (1863-1943). In The Principles of Judicial Proof (1913), he set forth an elaborate system of logic for analyzing evidence. His approach proved too complex for practical use, but several of the new scholars purported to make it more accessible. Some of their approaches developed in connection with the analysis of intelligence data in national security matters.

\section{Probability}

Part of the new evidence debate is whether probability theory should be included in evidence courses and in trials. Scholars agree that some notion of probability is necessarily involved in any deliberation about what to conclude from evidence. English law requires civil plaintiffs' verdicts to be based on "the balance of probabilities." American law uses "preponderance of the evidence" instead. Both standards mean the essential facts must be proved more probable than not. In criminal cases, the standard is "beyond a reasonable doubt." This does not require certitude either - only a very high order of probability. Furthermore, U.S. evidence rules declare evidence relevant if it has any tendency to make a matter of consequence to the litigation "more probable or less probable than it would be without the evidence" (Federal Rules of Evidence [FRE] 401). 
Thus, fact finders necessarily consider probability. A jury may have to assess the probability that one who writes a love letter (introduced in evidence in a murder trial against the writer) might kill the spouse of the object of his love. Or the probability that the defendant's attempted suicide in jail while awaiting trial indicates consciousness of guilt of the charged offense. Or the probability that two different couples would have the same ten identical characteristics shown to be possessed by both the couple at the scene of the robbery and the couple on trial for the robbery.

Although trials routinely require probability assessments, the question is, how precise should they be? Is common lay experience enough? Should expert testimony concerning probabilities, frequencies, or statistics play a role? Should the judge instruct the jury in mathematical probability formulas? Can lawyers and judges learn anything useful from probability theory? The dispute often centers on whether Bayes's Theorem - a complicated mathematical formula for how previous probability estimates are affected by new evidence - should play a role. Scholars debate while judicial decisions on these issues are mixed.

A related issue is whether a mere preponderance of probability is enough to produce a verdict for the plaintiff in a civil case, or whether a conclusion that there is a preponderance of probability is insufficient if based on a low (or nonspecific) quantum of evidence. Suppose only a minimal amount of evidence is available - perhaps addressing only how things operate in general — but after hearing this evidence, a plaintiff's proposition quite rationally appears more probable than any contrary proposition. Is this sufficient for a plaintiff's verdict?

Could a jury find that the bus that hit a plaintiff belonged to the defendant bus company rather than to the other licensed bus company in town simply because the defendant operates more buses there than the other company and it is conceded no third company's bus could have been involved? Can one conclude the defendant ballpark patron was a nonpaying gate-crasher simply from the fact that he was one of the 1,000 customers of the ballpark on that occasion and that only 499 tickets were sold and that 501 of the attendees were gate-crashers? The controversy pointedly occurs in lawsuits alleging injury from exposure to toxic substances or pharmaceuticals. Plaintiffs often seek verdicts simply based on epidemiological studies showing that exposed populations exhibit more than double the incidence of the injury than do identical populations not so exposed. The decisions are varied.

Since the infamous September 11, 2001, attack on the New York World Trade Center, there has been renewed interest among national defense intelligence analysts in probability. Faulty intelligence about Iraq's "mass destruction weapons" has stimulated inquiry into how intelligence estimates might more clearly reveal their probability, certainty, or confidence level.

\section{Storytelling}

A related controversy involves the extent to which one reasons inductively or deductively in making factual findings. Does each piece of evidence cumulatively add up to a picture or do jurors start with several preconceived, relatively completed, alternative stories of what might have happened (for example, unprovoked murder or self-defense) and then decide which story the evidence fits best? This has strategic implications for advocates.

\section{Empirical Testing}

Scholars divide over the importance of empirical testing of the traditional beliefs that "justify" rules of evidence - for instance, the belief that jurors will be too ready to convict if they are allowed to hear about a defendant's collateral crimes, or that spouses will communicate more if there is a privilege embracing 
their confidential communications. Some scholars try to test these propositions. There is controversy, for example, among the courts in the United States as to whether, when, and in what form to allow expert testimony or jury instructions based on empirical experiments demonstrating that eyewitnesses are not as reliable as they might seem. In a somewhat related vein, some evidence scholars seek to ascertain whether evidence rules and rulings have unexpected effects on the welfare of women, while others are applying economic concepts to ascertain any more general societal effects.

\section{Current Controversies about Particular Rules of Evidence}

\section{Expert Evidence}

The U.S. Supreme Court's decision in Daubert v. Merrell Dow Pharmaceuticals, Inc. (509 U.S. 579, 1993) sparked a revolution that continues, concerning the standard for admissibility of civil and criminal scientific evidence. The decision applies only to federal courts, but it influences states as well, many of whom, however, still decline to expressly adopt it. Kumho Tire Co., Ltd. v. Carmichael (526 U.S. 137, 1999) extended Daubert to all expert or specialist evidence, not merely that which purports to be scientific.

Previously, the predominant test for scientific evidence among federal and state courts was that articulated by Frye v. United States (293 F. 1013, D.C. Cir., 1923): The admissibility of "expert testimony deduced from... [a] scientific principle or discovery" hinges on whether or not "the thing from which the deduction is made...[is] sufficiently established to have gained general acceptance in the particular field in which it belongs." Daubert radically shifted the trial judge's duty away from making that determination, to making a more independent one not quite so deferential to the "field." The judge must determine (as a precondition to admissibility) whether the testimony, though not free from all doubt and not immune to contrary expert testimony, has a certain degree of reliability, in that it was derived by the "scientific method," earmarked by testing, peer review, low error rates, professional standards, and acceptance in the scientific community. Scholars question whether this properly captures the scientific method.

The "acceptance" earmark is reminiscent of Frye, but is not dispositive as it was under that case, leading some commentators to call the new test "Frye Plus" or "Frye Minus" because it can be more, or less, demanding than Frye, depending upon the context. For example, older forensic techniques rather blindly accepted evidence such as identification by fingerprints, handwriting, ballistics, tool marks, hair, and fibers. These matters are currently undergoing reexamination to see if they truly have the scientific underpinning demanded by Daubert. Conversely, new techniques that have no established track recordand thus cannot be said to have general acceptance under Frye-may still be proved scientific enough to be admissible under Daubert. Older techniques such as polygraphic lie detection, rejected under Frye, are also under reevaluation.

Although other countries have not expressly adopted the Daubert test, there is similar foment internationally. In several recent high-profile U.K. and U.S. prosecutions in which a parent is charged with killing his or her child, controversy has arisen over the prosecution's expert testimony. The expert's thrust is that the likelihood is very low of more than one infant death in a family occurring because of Sudden Infant Death Syndrome (SIDS, or "crib or cot death") — an unexplained but natural cause of death. The defense typically claims the child's death is not homicide but an instance of SIDS. The prosecution answers that another child of the same family has died previously, which the defense also attributed to SIDS. A prosecution expert then testifies that multiple SIDS deaths in the same family are extremely improbable. However, scientists are raising questions about whether there may be a genetic or 
other innocent predisposition in families to SIDS, in which case the extreme improbability figures adduced by the prosecution's expert may be erroneous. Judges are now reexamining convictions and custody determinations in both countries. This involves both the issues of scientific evidence and probability.

Forensic DNA encompasses a similar intersection of these two issues. DNA identification, as do some other forensic techniques, necessarily involves expert testimony about probabilities based on the frequency in the population of certain biological or related characteristics. While judges now routinely accept several forms of DNA identification if properly done, newer forms generate controversy as to both their basic theory and the population genetics that provide the foundation for the probability-of-match estimates. Even when the population genetics is not questioned, there is debate about how match probabilities should be expressed to the fact finder. Should lawyers and judges use general lay terms or precise numbers? Judicial decisions vary.

\section{Confrontation}

The U.S. Constitution's Sixth Amendment provides, "the [criminal] accused shall enjoy the right...to be confronted with the witnesses against him." The Supreme Court interprets this to mean witnesses must be presented in open court, subject to cross-examination with the possibility of perjury penalties. Until 2004, prosecution use of out-of-court statements was permitted if the statement complied with some "firmly rooted" exception to the hearsay rule or was otherwise proved particularly reliable. In Crawford $v$. Washington (541 U.S. 36, 2004), the Supreme Court overruled this position, and held that such statements violate confrontation if they are "testimonial" in nature, unless there was an opportunity for crossexamination at trial or on a previous occasion.

What is to be deemed "testimonial" was left vague. The Court hinted that it had something to do with whether the statement was garnered by officials, its maker realized it had legal potential, or it was given in an interrogation or formalized setting. Crawford held only that, because the accused's wife made statements under a formal police interrogation at the station house, which statements arguably were contrary to his version of the allegedly criminal assault, they were "testimonial" under any likely definition.

Controversy has raged ever since in state and federal courts about what beyond that particular situation is covered by the term testimonial. Of special difficulty have been statements made in "911" calls (emergency calls ostensibly seeking help) or on the scene of an alleged crime, and excited utterances generally. Questions are also raised as to what kind of police involvement, interrogation, formality, and intention are required, for either the police or suspect, if any. Also unclear is whether the former scheme looking to "firmly rooted" hearsay exceptions or particular guarantees of trustworthiness still has viability if the statement is not regarded as testimonial.

\section{Character Evidence}

The common law held evidence of one's character (including one's collateral bad acts) inadmissible to prove he acted in conformity with that character, with certain exceptions. The British Parliament, pt. II, ch. 1, Criminal Justice Act, 2003, effective December 2004, extensively reformulated the rules on such evidence in criminal cases, and uncertainty prevails concerning what the new provisions mean. They seem to open the door widely to the bad character of the accused, and there is some possibility this may collide with the European Convention on Human Rights. 
The U.S. FRE and state rules establish a dichotomy between bad acts used to show conformity with character (generally forbidden) and certain more specific uses (generally permitted). The differentiation continues to cause practical and theoretical problems. Some authorities believe that the "doctrine of chances"- a method of analysis that relies on the improbability of a person being involved in multiple bad acts of the same kind - justifies using bad acts in a way that might otherwise appear to violate the character ban. Nevertheless, other scholars believe this is only circumlocution and that a better approach to understanding the line between the two is to differentiate specific propensity from general character.

In 1994, responding to a spate of sex offenses, Congress, over the objection of the courts, amended the FRE to more freely permit evidence of other crimes committed by alleged sex offenders and child molesters. A few states followed suit. It is too early to tell whether this approach will spread to other offenses. Courts are undecided whether the new provisions allow or the Constitution demands some judicial discretion to exclude.

"Rape shield" provisions guarding sexual offense victims from character assassination at trial continue to give rise to interpretive difficulties, especially when they interfere with a criminal defendant's fair "right to defend" under the due process, compulsory process, and confrontation provisions of the U.S. and state constitutions. Indeed, the scope of this "right to defend" has been controversial and uncertain wherever evidence rules (for example, third-party privilege, or the hearsay rule) operate to deprive a criminal defendant of evidence. A similar controversy should arise pursuant to the European Convention on Human Rights, which in some measure is the European equivalent of the U.S. Constitution on these issues.

\section{Privilege}

American companies are accustomed to a broader attorney-client privilege than is available in the United Kingdom and some continental countries. For example, in England, what is regarded as professional legal advice covered by privilege is considerably narrower than in the United States. Nevertheless, the Bank of England recently won a House of Lords victory (in Three Rivers District Council v. Bank of England [2004] UKHL 48 2005), overturning a decision that advice from attorneys concerning how to present in a government inquiry was not legal advice. In France, corporate in-house attorneys are not covered by the privilege. These matters continue to give rise to controversies involving American companies operating overseas. There is also some dispute about how far the European Convention on Human Rights constrains member nations from enforcing restrictions on personal privileges.

Controversy persists among U.S. states about whether to adopt the federal standard of Upjohn Co. v. United States (449 U.S. 383, 1981), under which corporate attorney-client privilege can cover lawyer communications not only with members of the company's control group, but also with lower-echelon employees. Furthermore, in 2002, Congress enacted the Sarbanes-Oxley Act in response to massive financial frauds committed by officers of the Enron Corporation and others. Regulations under the act permit or require corporate lawyers to report suspected wrongdoing in the ranks of their corporate client. Scholars expect this to narrow the attorney-client privilege, but results are not yet in.

\section{Electronic Evidence}

In most developed countries, problems continue to arise concerning how rules of evidence designed before the advent of computers apply to various forms of electronic evidence. Several jurisdictions - such as the Philippines - have or are devising special provisions for electronic evidence.

\section{Evidence in Terrorism Cases}


Global terrorism presents a problem concerning not only whether officials should try suspected terrorists in the regular courts or special tribunals, but also what, if any, modification of normal procedures and rules of evidence one should make to accommodate national security and state or military secrets. This has been particularly vexing in the United States but has affected other countries as well. The law is in a state of flux.

\section{Conditional Relevance}

FRE 104(b) embodies a concept found everywhere in common law jurisdictions: that in some instances, a piece of evidence may be relevant only if some other fact is found true. For example, a shout "I fell asleep" from inside a car after an accident may be relevant in an auto accident case against the driver only if it is found that the voice was that of the driver. Documents may be relevant only if one proves the signature on them is genuine. A gun found in the possession of the defendant may be relevant only if one demonstrates it was used in the crime.

Some scholars, however, posit that the evidence in these examples is relevant (not necessarily admissible) without any proof of the other fact, because the common definition of relevant evidence is evidence that increases a pertinent probability in any degree. So long as the shout may have been by the driver, it increases the probability that the driver so shouted. A signature purporting to be mine increases the probability it is mine compared with a situation where there is no such signature or a contrary one. Since the gun may have been the one used in the crime, the possibility that it was is increased.

Consequently, courts are somewhat uncertain how to rule, and lawyers have made arguments for both relevance and irrelevance in the same case.

- Paul F. Rothstein

\section{Further Readings}

Allen, Ronald. "The Nature of Juridical Proof." Cardozo Law Review, 13, (1991). 373-422.

Anderson, Terrence; David Schum; William Twining. (2005). Analysis of Evidence, 2d ed. Cambridge: Cambridge University Press.

Cohen, L. Jonathan (1977). The Probable and the Provable. Oxford: Clarendon Press.

Damaska, Mirjan. (1990). “Atomistic and Holistic Evaluation of Evidence: A Comparative View." In Comparative and Private International Law: Essays in Honor of John Henry Merryman on His Seventieth Birthday, edited by Clark, David S.. Berlin: Duncker \& Humblot, 91-104.

Finkelstein, Michael O.; William B. Fairley. "A Bayesian Approach to Identification Evidence.” Harvard Law Review, 83, (1969). 489-517.

Pardo, Michael. “The Paradoxes of Legal Proof: A Critical Guide.” Boston University Law Review, 99, (2019). 233-50.

Rothstein, Paul F. "Intellectual Coherence in an Evidence Code." Loyola Los Angeles Law Review, 28, (1995). 1259. 
Symposium. "Decision and Inference in Litigation.” Cardozo Law Review, 13, (1991). 253-1079. . “The Science of Proof.” South Texas Law Review, 40, (1999). 327.

__. "New Perspectives on Evidence.” Virginia Law Review, 87, (2001). 2029.

—. "Visions of Rationality in Evidence." Michigan State Law Review, 2003, (2003). 847.

Tillers, Peter; Eric D. Green, eds. (1998). Probability and Inference in the Law of Evidence: The Uses and Limits of Bayesianism. Dordrecht, Netherlands: Kluwer Academic.

Tribe, Laurence. "Trial by Mathematics: Precision and Ritual in the Legal Process." Harvard Law Review, 84, (1970). 1329-93.

Twining, William. (1990). Rethinking Evidence: Exploratory Essays. Oxford: Blackwell.

—. "Evidence as a Multi-disciplinary Subject." Law, Probability and Risk, 2, (2003). 91-107. 